\title{
Status of Women Education in India with Particular Reference to Women Empowerment and Development
}

\author{
KalpanaSaxena, Asst. Prof. (B.Ed. Faculty), Jyoti College of Education, \\ Sehore,M.P.
}

\begin{abstract}
ABSRACT:- Women education guarantees better advancement of human progress, as well as to instruct after that era as well. Education is point of interest of women empowerment since it encourages them to react to the difficulties, to stand up to their standard appearance and upset their living. Women education in India has additionally been a noteworthy distraction of both the administration and common society as taught women can assume an essential part in the improvement of the nation. Education is point of reference of women empowerment since it empowers them to reacts to the difficulties, to go up against their conventional part and change their life. With the goal that we can't disregard the significance of education and development in reference to women empowerment India is ready to getting to be superpower, a created nation by 2020 . The development of women's education in country regions is moderate. This clearly implies still extensive womenfolk of our nation are uneducated, the powerless, in reverse and misused. Education of women in the perspective of training and development is the most effective apparatus of progress of position in the public eye.This paper looks at the issue of women's access to education in India. Drawing on existing writing and different insights concerning women's education, the paper gives a diagram of the condition of education as for women and highlights a portion of the issues and obstructions to women's education. In view of an investigation of rising issues, a few proposals and recommendations are offered as far as grassroots level intercessions, key activities and empowering strategy system, towards enhancing women's access to education.
\end{abstract}

Keywords: Education, Women empowerment, Development, Economic Development.

\section{INTRODUCTION}

Women education in India assumes an essential part in the general advancement of the nation. It not just aides in the improvement of half of the human resources, however in enhancing the personal satisfaction at home and outside. Educated women not just have a tendency to advance education of their young lady kids; additionally can give better direction to every one of their youngsters. In addition educated ladies can likewise help in the diminishment of newborn child death rate and development of the populace.

\section{HISTORICAL PARADIGM OF WOMEN EDUCATION IN INDIA}

In spite of the fact that in the Vedic period, women had permission to education in India, they had bit by bit lost this privilege. In the British time frame, there was increment of enthusiasm for women's education in India. Amid this period, different socio religious operations drove by prominent people like Raja Ram Mohan Roy, Iswar Chandra Vidyasagar underlined on women's education and connection with external world in India. However women's education got a quick augmentation after the nation got autonomy in 1947 and the government has taken different measures and activities to give education to all Indian ladies. Subsequently women's proficiency rate has become over the three decades and the development of female proficiency has in certainty been higher than that of men education rate for little a long time. While in 1971 just $22 \%$ of Indian women were proficient, before the end of $200154.16 \%$ female were proficient.

\section{SIGNIFICANCE OF WOMEN EDUCATION IN INDIA}

Sexual orientation disparity in education is extraordinary. In India young women were less inclined to get to school, to stay in school or to accomplish in education. Be that as it may, now the situation is changing and families understand the significance of education. Women education in India assumes an essential part in the general development of the nation. It not just makes a difference in the advancement of half of the human capital, however in enhancing the standard of living. Taught women not just have a tendency to advance training of their young women children; however additionally can give better direction to every one of their youngsters 
and their future. Also taught women can likewise help in the lessening of neediness and unemployment by supporting their families' completely.

\section{WOMEN EMPOWERMENT IN INDIA}

Women empowerment alludes to expanding the otherworldly, political, social, instructive, sexual orientation or monetary quality of people and groups of women. Women empowerment in India is intensely reliant on a wide range of factors that incorporate topographical area (urban/rustic) instructive status societal position (standing and class) and age. Approaches on Women empowerment exist at the national, state and nearby (Panchayat) levels in numerous divisions, including wellbeing, training, monetary open doors, sexual orientation based viciousness and political interest. However there are huge hole between strategy headways and genuine practice at the group level.

Women empowerment is basically the procedure of upliftment of financial, social and political status of ladies, the generally underprivileged ones, in the general public. It is the way toward guarding them against all types of brutality. Women empowerment includes the working up of a general public, a political situation, wherein women can inhale without the dread of abuse, misuse, worry, segregation and the general sentiment oppression which runs with being a lady in a customarily male ruled structure.

Women constitute just about half of the total populace yet India has indicated unbalanced sex proportion whereby female's populace has been relatively lower than guys. To the extent their societal position is concerned, they are not regarded as equivalent to men in every one of the spots. In the Western social orders, the ladies have measure up to right and status with men in all kinds of different backgrounds. However, gender disabilities and discriminationsare found in India even today. The dumbfounding circumstance has with the end goal that she was in some cases worried as Goddess and at different times only as slave.

\section{STATUS OF WOMEN EMPOWERMENT}

The status of Women Empowerment can't be pictured with single measurement rather multidimensional appraisal regarding different segments of women' life and their status would bring a reasonable origination. In this way, this paper tries to give a fundamental thought regarding the condition and status of women in wording of empowerment, education, and economic development.

\section{HINDRANCES OF WOMEN EMPOWERMENT}

The main Problems that were faced by women in past days and still today up to some extent:

1. Gender discrimination

2. Lack of Education

3. Female Infanticide

4. Financial Constraints

5. Family Responsibility

6. Low Mobility

7. Low ability to bear Risk

8. Low need for achievement

9. Absence of ambition for the achievement

10. Social status

11. Dowry Marriage in same caste and child marriage (still existing)

12. Atrocities on Women (Raped, Kicked, Killed, Subdued, humiliated almost daily.)

\section{OBJECTIVES OF THE STUDY}

- To study the status and scenario of women education and women empowerment in India.

- To study the significance of women education and Women Empowerment in India.

- To analyze the Factors influencing the Economic Empowerment of Women.

- To identify the Hindrances in the Path of Women Empowerment with particular reference to education.

\section{REVIEW OF LITERATURE}

H. Subrahmanyam (2011) ${ }^{1}$ looks at women education in India at present and Past. Author highlighted that there has a decent advance in general enrolment of young women understudies in schools. The term engage intends to give legitimate power or power to act. It is the way toward securing a few exercises of women.

M. BhavaniSankaraRao (2011) ${ }^{2}$ highlighted that soundness of women individuals from SHG have surely taken a swing to better. It unmistakably demonstrates that heath of women individuals talk about among 
themselves about wellbeing related issues of different individuals and their youngsters and make them mindful of different Government arrangements uniquely implied for them.

Doepke M. Tertilt M. (2011) ${ }^{3}$ Does Female Empowerment Promote Economic Development? This study is an observational investigation recommending that cash in the hands of moms advantages youngsters. This study built up a progression of non-helpful family dealing models to comprehend what sort of grindings can offer ascent to the watched observational relationship.

Duflo E. (2011) ${ }^{4}$ Women's Empowerment and Economic Development, National Bureau of Economic Research Cambridge The study contends that the bury connections of the Empowerment and Development are presumably too powerless to be in any way self-managing and that consistent approach duty to similarly for its own particular purpose might be expected to achieve equity amongst men and ladies.

Sethuraman K. (2008) $)^{\mathbf{5}}$ The Role of Women's Empowerment and Domestic Violence in tyke Growth and under sustenance in a Tribal and Rural Community in South India; This examination paper investigates the relationship between Women's Empowerment and Domestic Violence, maternal nutritious status and the dietary status and development more than six months in kids matured 6 to 24 months in a provincial and tribal group.

Venkata Ravi and Venkatraman (2005) ${ }^{\mathbf{6}}$ concentrated on the impacts of SHG on women cooperation and practicing control over basic leadership both in family matters and in gathering exercises.

\section{RESEARCH METHODOLOGY}

This paper is fundamentally descriptive and analytical in nature. In this paper an endeavor has been taken to examine the women empowerment and development in India. The data and information utilized as a part of it is absolutely from auxiliary sources as indicated by the need of this study.

\section{FINDINGS OF THE STUDY}

- Globalization, Liberalization and other Socio - Economic strengths have given some relief to a vast extent of the populace. Be that as it may, there are still a significant number regions where women empowerment in India is to a great extent lacking.

- There should be an ocean - change in the attitude of the general population in the nation. Not only the women themselves, but rather the men need to wake up to wake up to a world that is moving towards balance and value. It is better this is grasped sooner than later for our own great.

- There are a few Government projects and NGOs in the Country, there is still a wide crevice that exists between those under assurance and those not.

- Neediness and ignorance add to these intricacies, The Empowerment of Women starts with an assurance of their wellbeing and security.

- Empowerment of Women must be accomplished if their monetary and societal position is made strides. This could be conceivable just by receiving distinct social and monetary arrangements with a perspective of aggregate improvement of women and to make them understand that they can possibly be solid people.

- Keeping in mind the end goal to make a feasible world, we should start to Empower Women.

\section{SUGGESTIONS OF THE STUDY}

- The most importantly need ought to be given to the women's education, which is the grassroots issue. Consequently, training for women must be given careful consideration.

- Mindfulness programs should be sorted out for making mindfulness among women particularly having a place with weaker segments about their rights.

- Women ought to be permitted to work and ought to be sufficiently given security and support to work. They ought to be given legitimate wages and work at standard with men so that their status can be hoisted in the general public.

- Strict execution of Programs and Acts ought to be there to control the mal-hones common in the general public.

\section{CONCLUSION}

"At the point when women push ahead the family moves, the town moves and the country moves". It is basic as their idea and their esteem frameworks lead the advancement of a decent family, great society and at last a decent country. The most ideal method for empowering is maybe through drafting women in the standard of advancement. Women empowerment will be genuine and successful just when they are enriched pay and property with the goal that they may remain on their feet and develop their personality in the general public. The Empowerment of Women has gotten to be a standout amongst the most essential worries of 21 st century at 
national level as well as at the global level. Government activities alone would not be adequate to accomplish this objective. Society must step up with regards to make an atmosphere in which there is no sexual orientation segregation and women have full chances of self-basic leadership and taking an interest in social, political and monetary existence of the nation with a feeling of equity.

\section{REFERNCES}

[1] Duflo E. (2011). Women's Empowerment and Economic Development, National Bureau of Economic Research, Cambridge.

[2] Doepke M. Tertilt M. (2011). Does Female Empowerment Promote Economic Development?News Paper Article.

[3] DasaratiBhuyan (2006)."Empowerment of Indian Women: A challenge of 21st Century" Orissa Review.

[4] DhrubaHazarika (2011). "Women Empowerment in India: a Brief Discussion" International Journal of Educational Planning \& Administration. Volume 1, Number 3 (2011)

[5] Kishor, S. and Gupta, K. (2009). Gender Equality and Women's Empowerment in India, NATIONAL FAMILY HEALTH SURVEY (NFHS-3) INDIA, 2005-06, and International Institute for Population Sciences, Deonar, Mumbai.

[6] M. BhavaniSankaraRao (2011).Education for Women Empowerment and Economic Development, IJRCMT Vol-1, pp; 17-18.

[7] Pankaj Kumar Baro1 \& Rahul Sarania (2011). "Employment and Educational Status: Challenges of Women Empowerment in India”, A Peer-Reviewed Indexed International Journal of Humanities \& Social Science.

[8] Sethuraman K. (2008). Empowerment of Women in India- Amovement for Tribal women education.

[9] Suguna, M., (2011). Education and Women Empowerment in India. ZENITH: International Journal of Multidisciplinary Research, 1(8), 19-21.

[10] Venkata Ravi and Venkatraman (2005). Empowerment of Women in India: A review of women's SHGs Movement in India.

[11] Vinze, MedhaDubashi (1987) "Women Empowerment of Indian: A Socio Economic study of Delhi" Mittal Publications, Delhi. 